\title{
All under one umbrella? The Family Guide to National Insurance 1948
}

\author{
JACKIE GULLAND
}

School of Social and Political Science, University of Edinburgh

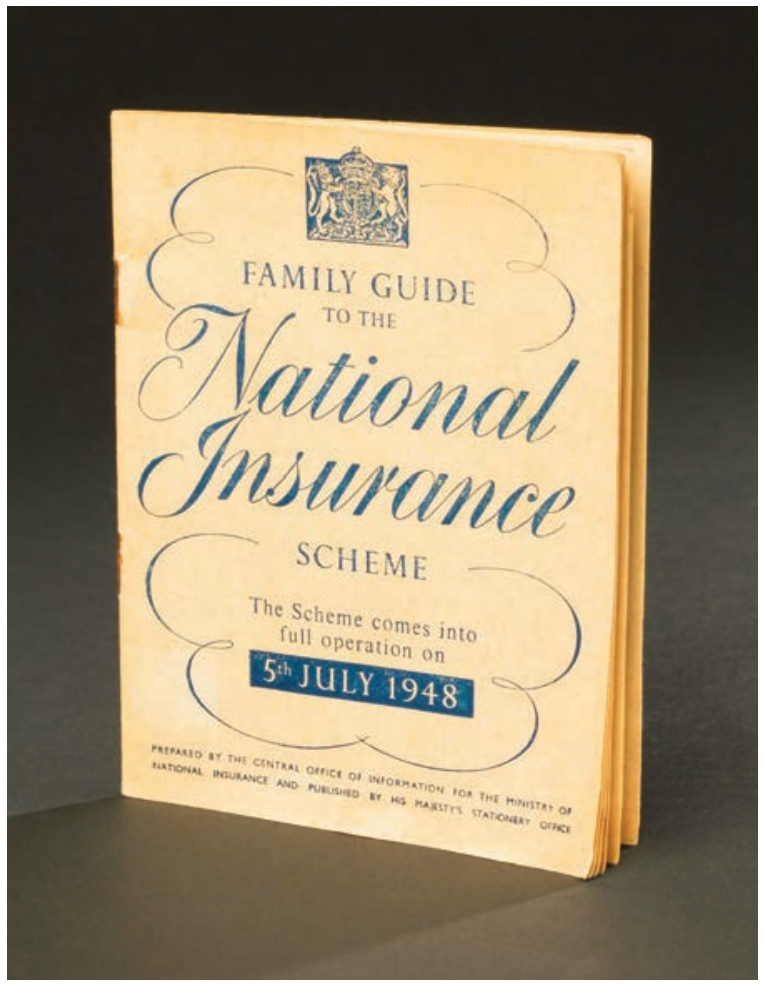

The Family Guide to the National Insurance Scheme

(C) Board of Trustees of the Science Museum†

Abstract

The Family Guide to National Insurance was produced in 1948 to coincide with the introduction of the British National Insurance scheme, inspired by the Beveridge Report. The Guide tells people about their legal rights, but it also symbolises a mid-twentieth-century enthusiasm for the welfare state. Making a model of the Guide for a socio-legal workshop helped to consider the physicality of the booklet and to think about how it might have been received by its readers. This article explores the meaning of the booklet, considering its form and its content but also its reception by the public. A survey conducted in 1948 concluded that the Guide had been unsuccessful in reaching those who could most benefit from it, particularly women. This article uses the findings of this survey to consider the booklet as a piece of public legal information and the role of legal consciousness in legal information provision.

Keywords: national insurance; public legal information; legal consciousness; welfare state; Beveridge Report.

$\dagger \quad<$ https://collection.sciencemuseum.org.uk/objects/co525210/booklet-family-guide-to-the-nationalinsurance-s-booklet> 


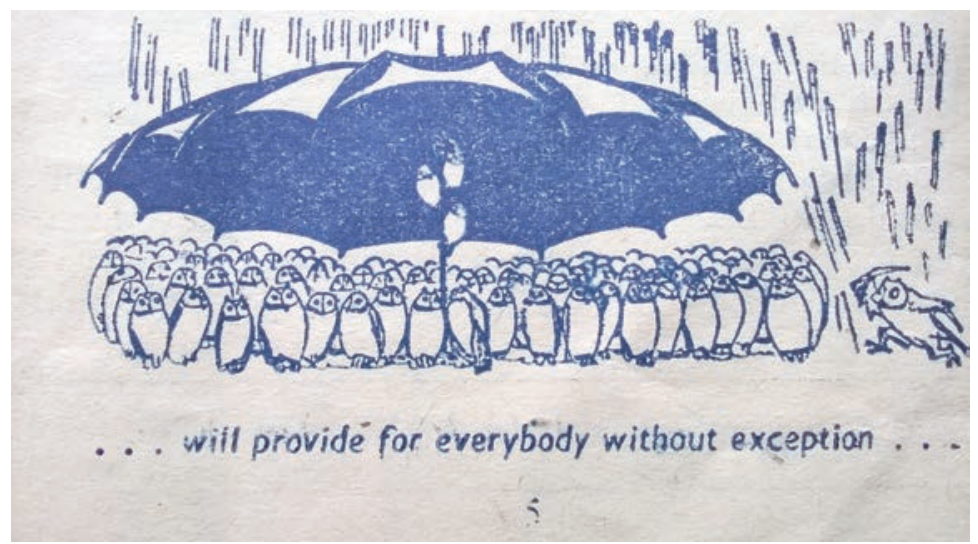

Figure 1: Owls under umbrella, illustration from the Family Guide, page 5, artist unknown Photo by Jackie Gulland

\section{The Family Guide to National Insurance}

$\mathrm{T}$ he Family Guide to National Insurance ${ }^{1}$ is a small brown booklet, slightly smaller than a postcard, printed with blue text. Highlighted in bold is a statement that the scheme 'Comes fully into effect on 5th July 1948'. We can see that this is an official British government document by the royal coat of arms at the top and, in smaller print at the foot, the text 'Prepared by the Central Office of Information for the Ministry of National Insurance and Published by His Majesty's Stationery Office'. There is a copy of the booklet in the Science Museum in London, where its accompanying description tells us that it is a ' 32 page booklet, $135 \mathrm{~mm} \times 110 \mathrm{~mm}$, illustrated'.

To the twenty-first-century reader, the Guide looks dated, the flimsy paper, a rather faded beige, suggestive of 1940s' austerity. Inside, there is a foreword by the Minister of National Insurance, the Rt Hon James Griffiths MP, which says:

. . . the 5th July 1948 will be a great day in the development of our British Social Services ... The system will provide for everybody without exception: men, women and children, young and old, rich and poor, married and single, employer and employed, those working on their own account, and those not working at all ...2

The booklet provides detailed information about how the National Insurance scheme would work. ${ }^{3}$ It tells people about their legal rights under the scheme: who was required to pay National Insurance contributions; how to claim benefits; the importance of time limits; and rights of appeal. The text is in blue and is in fairly small type, densely written and running to around 10,000 words. There are headings and paragraph numbers to denote different sections. A striking feature of the Guide is that there are also illustrations breaking up the text. It is illustrated with cartoon owls: owls claiming benefits, chasing their order books, feeding their children and sheltering under a giant umbrella (Figure 1).

1 Ministry of National Insurance, Family Guide to the National Insurance Scheme (HMSO 1948), hereafter Family Guide/the Guide.

2 Ibid 3.

3 This was introduced by the National Insurance Act 1946. Although there was almost identical parallel legislation for National Insurance in Northern Ireland, this was the responsibility of the Northern Ireland government, see John Ditch, Social Policy in Northern Ireland between 1939-1950 (Avebury 1988); Derek Birrell and Deirdre Heenan, 'Devolution and Social Security: The Anomaly of Northern Ireland' (2010) 18 Journal of Poverty and Social Justice 281. 
The Ministry of Information printed 14 million copies of the booklet and distributed a copy to every household in England, Wales and Scotland to coincide with the introduction of the new National Insurance scheme in July 1948. Copies were also printed in Welsh. ${ }^{4}$

\section{Research context: understanding incapacity for work}

My research concerns the development of social security benefits for people who are considered to be incapable of work. ${ }^{5}$ This research uses socio-legal sources: legislation, records of appeals against refusal of benefits and a variety of official government documents regarding the introduction and development of ideas about incapacity for work' across the twentieth century. This research starts in 1911, with the introduction of the first state National Insurance scheme in the UK and continues through the founding of the classic 'Beveridgean' welfare state, established in the 1940s, and up to the present day, with continuing debates about who should qualify for benefits and how these should be assessed. By following the development of the concept of incapacity for work through legislation, case law and policy, my research seeks to answer questions about the meaning of 'work', the meaning of 'incapacity' and the gendered context in which these ideas operate. The Family Guide to National Insurance represents a point in time in the development of these ideas, with the introduction of a comprehensive social insurance scheme which provided non-means-tested contributory sickness benefits for people who were incapable of work. ${ }^{6}$ The introduction of the British post-war welfare state has been well documented and researched by policy analysts, historians and socio-legal researchers. ${ }^{7}$ While the booklet itself does not tell us anything new about the content of the post-war National Insurance scheme, it does provide a tangible symbol of an important time in the development of social security systems.

\section{Finding the Family Guide}

The Guide first came to my attention when I was working through a box of archive documents about the 1911 National Insurance scheme. Thirty-seven years of history, two world wars and the creation of the post-war welfare state had passed between the other leaflets in this box and the Family Guide. It was in the wrong place. I might have overlooked it, had it not been for the illustrations. I was struck by the contrast between the dense, legalistic text and the quirky, if rather patronising, images of owls. This led me to try and find out more about the Guide. I found more copies in collections of papers in archives across the UK. There are copies in the London Science Museum, the British Library, the Wellcome Library, the Public Record Office of Northern Ireland and in the universities of Warwick and Leeds. The Guide is listed in books and online sales sites as a collectable item of 'ephemera'. I found my own copy in the listing of a second-hand bookseller. These few copies of the Guide provide only a very small trace of the original 14 million

4 HC Deb, 11 May 1948, vol 450, para 37.

5 This research was carried out for a Leverhulme Early Career Research Fellowship at the University of Edinburgh, 'Constructing Incapacity for Work: Conditionality in Sickness Benefits since 1911', funded by the Leverhulme Trust. (ECF-2012-178). For more information about this research, see $<$ www.blogs.hss.ed.ac.uk/constructingincapacity>.

6 The scheme also provided cash benefits for retirement, unemployment, widowhood and industrial injuries, as well as maternity and death grants.

7 For example, Derek Fraser, The Evolution of the British Welfare State (4th edn, Macmillan 2009); Neville Harris, 'Beveridge and Beyond: The Shift from Insurance to Means-testing' in Neville Harris (ed), Social Security Law in Context (Oxford University Press 2000); Rodney Lowe, The Welfare State in Britain since 1945 (Macmillan 1993); Nicholas Timmins, The Five Giants: A Biography of the Welfare State (Harper Collins 1995). 
and I have yet to find a copy in Welsh. During my searches, I also found a public information film, made in July 1948, encouraging people to read the booklet, to keep it safely and not to throw it out. ${ }^{8}$ The film stars a popular comedian of the time, Tommy Trinder, who finds a 'housewife' about to tear up the booklet and tells her to keep it. Advertisements referring to the Guide were also carried in newspapers. For example, an advertisement in The Times reminded readers to look at the Guide for advice on National Insurance contributions for self-employed people. ${ }^{9}$ In my search for more information about the booklet, I discovered a copy of the findings of a survey on how the booklet was received by the general public. ${ }^{10}$ This survey consisted of 1001 face-to-face interviews and asked questions about whether or not people had seen the booklet, whether they had read it and what they had gleaned from the information in it.

\section{The social context of the Family Guide}

In his article on exploring material culture, Prown describes objects as reflecting 'the beliefs of individuals who made, commissioned, purchased or used them, and, by extension, the beliefs of the larger society to which they belonged'. ${ }^{11}$ The Family Guide can be considered from the perspectives of each of these groups.

The first group, the person or people who 'made' the object, is invisible. I have tried to trace information about the production of the Guide, including the drafting of the text and the illustrator, but have so far failed to find out anything about these individuals. A tantalising entry in the National Archives catalogue tells us that a set of National Insurance Advisory Committee papers on the Guide is 'missing at transfer'. ${ }^{12}$ On the other hand, I do have some information about the people who commissioned the Guide. This is clear from the Guide itself. It was 'Prepared by the Central Office of Information for the Ministry of National Insurance'. It was commissioned by a government ministry with the intention of providing public information about the National Insurance scheme. The idea of social insurance had been promoted by Beveridge as a collective mechanism to banish the giant of 'want' and the miseries of the inter-war means test, while maintaining individual responsibility to work and pay contributions. ${ }^{13}$ Beveridge's vision, although somewhat altered in the National Insurance Act 1946, was rooted in assumptions about the role of the state in maintaining full employment and the existence of a National Health Service (NHS), funded through taxation. It represented a particular model of citizenship which depended on collective provision, combined with individual responsibility, a strong work ethic and a patriarchal model of family structure. National Insurance had been promoted as socially beneficial, something for everyone, and had received a degree of political consensus at the time. This enthusiasm is often exemplified in histories of the welfare state by the image of people queuing all night to buy copies of the Beveridge Report in $1942 .{ }^{14}$ There were critics of the scheme at the time and the

8 Tommy Trinder Family Guide (British Pathé 1948) <www.britishpathe.com/video/tommy-trinder-family-guidetrailer>.

9 'National Insurance' The Times (London 11 June 1948) 2.

10 H D Willcock, The Family Guide to the National Insurance Scheme: An Inquiry Made by the Social Survey for the Ministry of National Insurance July 1948 (HMSO 1948), filed in National Archives RG23/143A.

11 Jules Prown, 'Mind in Matter: An Introduction to Material Culture, Theory and Method' (1982) 17(1) Winterthur Portfolio 1-19, 2.

12 National Archives PIN 60/11 <http://discovery.nationalarchives.gov.uk/details/r/C1368765>.

13 Sir William Beveridge, Social Insurance and Allied Services (Cmnd 6404 1942).

14 Timmins (n 7) 23. 
political consensus on the role of National Insurance was not to last, ${ }^{15}$ but the 'appointed day' was welcomed by The Times on 5 July 1948:

Today the British people join together in a single national friendly society for mutual support during the common misfortunes of life. ${ }^{16}$

Setting up the scheme was an enormous administrative task, involving 39,000 new staff, 1000 new local offices and a 14-acre administrative centre, with its own railway station. ${ }^{17}$ The Ministry of National Insurance had a major task to educate the population about the workings of the new scheme, while promoting the role of National Insurance as part of the post-war nation-building welfare state. Fraser describes the publicity drive as preparing the nation 'psychologically' for the new scheme. ${ }^{18}$ The Guide had a dual role in educating the public about their rights and responsibilities, while acting as propaganda in promoting the idea of National Insurance and the welfare state.

Finally, we can think about the people who 'used' the Guide. The intended readers were the people who might be expected to contribute to the National Insurance scheme and to claim the benefits which it created. But this group is rather smaller than the general public as a whole. The scheme is described in the Guide as for 'everyone without exception', but it excluded some groups in society, for example, disabled people who had been excluded from the labour market or who found it difficult to maintain a conventional working pattern ${ }^{19}$ and it was heavily gendered in its assumptions about the male breadwinner model and the household division of labour. ${ }^{20}$ The title of the booklet, The Family Guide, and the references to husbands, wives, housewives and families carry strong assumptions about the nature of domestic lives and roles. The survey about the reception of the Guide can tell us more about its expected readership. The population used to provide the survey sample was people 'aged 18-64 in Great Britain' and a quota sampling method was used to ensure an appropriate distribution of respondents by gender, age, marital status, occupational class, geographical region and urban and rural areas. $^{21}$ Although retirement pensions were an important element of the National Insurance scheme, the Guide itself was clearly aimed primarily at those of 'working age' and those living in private households. There was an assumption that the readers of the Guide would be literate and would read in English, despite the fact that a version had been produced in Welsh.

Strangely, the survey report seems to make little reference to the wider publicity strategy, with no mention, for example, of the Tommy Trinder film. Respondents were asked where else they had heard about the new scheme, but only 3 per cent of those surveyed in this study mentioned having seen reference to the new scheme in 'films', suggesting that the film had not been a major source of information.

15 Lowe (n 7); Timmins (n 7).

16 The Times, 5 July 1948, cited in Margaret Jones and Rodney Lowe, From Beveridge to Blair: The First Fifty Years of Britain's Welfare State 1948-98 (Manchester University Press 2002) 49-50.

17 Timmins (n 7) 137-8.

18 Fraser (n 7) 276.

19 Anne Borsay, Disability and Social Policy in Britain since 1750: A History of Exclusion (Palgrave Macmillan 2004).

20 Ruth Lister, “She Has Other Duties" - Women, Citizenship and Social Security', in Sally Baldwin and Jane Falkingham (eds), Social Security and Social Change: New Challenges to the Beveridge Model (Harvester Wheatsheaf 1994).

21 Willcock (n 10) 40. 


\section{Ignored by those who could most benefit from it?}

The survey report concludes that the Guide had been largely ineffective: many respondents did not remember receiving it and those that had read it were confused about the content. In particular, respondents were confused about the relationship between the National Insurance scheme and the new NHS. This was not surprising, given that the prewar national health insurance scheme had linked contributions and health care provision and that there was a parallel publicity scheme for the NHS. There is no reference in the survey report to an almost identical-looking guide to the NHS, which was distributed around the same time 22 and which may have led to some confusion between the two schemes.

The report concludes that the Guide had been ignored by those who could most benefit from it'. ${ }^{23}$ The report's author believed that many people did not read the Guide because they thought it would be difficult and boring. The author of the report blamed the cover for looking official and difficult. This focus on the form of the Guide can be seen in several references to its appearance:

The report should be read with this external appearance in mind. Attention is drawn to two points a) that the Guide was revealed by its cover to be an official publication; and b) that the words NATIONAL INSURANCE, the only immediate indication of its contents, might well have caused the less initiated to confuse it with the old National Health Insurance. ${ }^{24}$

This description of the front cover focuses on the official nature of its appearance, one that cannot be denied. The survey report provides further descriptive detail:

On the front cover of the Guide the Royal Arms are displayed top centre; on the back cover, the Crown surmounting the letters MNI (Ministry of National Insurance) . . . on the back cover it is stated that additional copies may be purchased 'at any local National Insurance Office, from His Majesty's Stationery Office ... or through any bookseller'. The two covers are otherwise identical ... the words NATIONAL INSURANCE are printed in large leaded script, the rest of the wording in considerably smaller type. A document which arrives unaddressed on the doormat has a big job of penetration to do, and nothing but its external appearance to assure its success ... In this process the cover is of major importance. ${ }^{25}$

Surprisingly there is no reference in the survey report to the illustrations and very little reference to the contents, other than that it was a booklet 'outlining the main provisions of the (National Insurance) scheme'.

One of the general conclusions of the report is that the information had been badly targeted. It had failed to attract the attention of those who could most benefit, described variously as 'the poorer classes', those of 'sub-average awareness', 'the uninformed' and women:

... it is possible that official publicity aimed primarily at the uninformed sections of the community might achieve its principle object of increasing overall informedness more successfully than the present type, which is usually directed - designedly or not - towards those of average or above-average intelligence or receptivity. It is on the face of it a curious reflexion that the guide, seeking as it

22 Copy available at <http:// museum.hackney.gov.uk/object9232>.

23 Willcock (n 10) 8.

24 Ibid 1.

25 Ibid 9. 


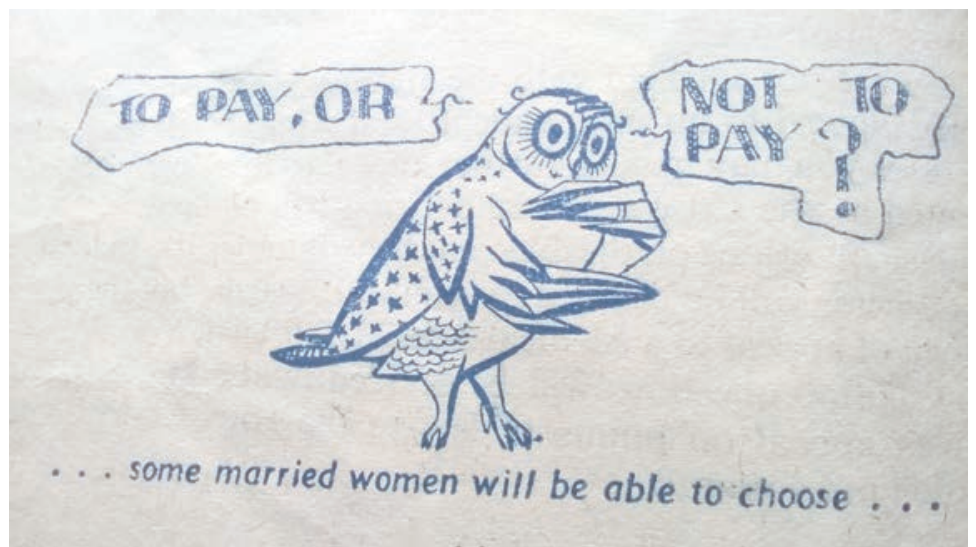

Figure 2: To pay or not to pay, illustration from the Family Guide, page 14, artist unknown Photo by Jackie Gulland

did to impart information on a scheme of particular benefit to the poorer classes and widely regarded and described as a scheme to 'help the working class', should have penetrated these classes least successfully.

... It might well be a productive experiment to leave the habitually betterinformed, the more intelligent and the more receptive, to obtain their information from the numerous alternative sources to which they are accustomed to refer, and to circulate information couched in format and terms designed principally to attract the attention of people of sub-average awareness - who do, after all constitute the majority of the uninformed. ${ }^{26}$

These 'classes' of people are contrasted with 'the more intelligent', 'the more receptive', 'the habitually better informed', who are well able to find information elsewhere. This is couched in a paternalistic language that suggests that all that is required is more simply worded leaflets, targeted at this less well-informed population. The survey was particularly interested in whether or not women had read or understood the Guide. In the survey report, women are generally dismissed as being less able to cope with complex information than men:

Among married women, especially those who were not at work, a virtual chaos of uncertainty and misinformation prevailed. This cannot be attributed specifically to the Guide, since it is a notorious phenomenon in survey results that women understand any slightly complex problem less clearly than men. ${ }^{27}$

This writing-off of women as less able to understand complex information fails to take account of the fact that the system of National Insurance was more complex in its relevance to married women or to women who might marry in the future. The section on 'Married Women' in the Guide does not really provide much clarity, saying that 'subject to certain conditions ... women will be able to choose whether they wish to go on paying for National Insurance'28 and then refers readers to another leaflet which would explain. This section is, rather unhelpfully, illustrated by an image of an owl unable to make up her mind about what to do (Figure 2).

26 Ibid 8.

27 Ibid 7.

28 Family Guide (n 1) 15. 


\section{Public information or propaganda: the contribution of legal consciousness}

The discussion in the survey report about the different propensities of people in broad social classes to engage with government information is evocative of much more recent attempts at improving public legal education or 'legal capability'. Recent policy work has focused on the importance of knowledge and education in people's propensity to deal with legal problems, sometimes described as 'legal capability'. ${ }^{29}$ Legal consciousness literature, on the other hand, identifies much more complex questions of power, inequality and culture, which are less easily addressed by information and education. Merry has described legal consciousness as 'the way people conceive of the natural and normal way of doing things . . . their commonsense understanding of the world'. ${ }^{30}$ Legal consciousness literature stresses that people's attitudes to the law are framed by the social and cultural context of their lives. Ewick and Silbey's framework of 'schemas' and 'resources' is helpful in understanding this, where schemas concern those symbolic features of people's lives which encourage or constrain legal action and 'resources' relate to the more practical resources of education, finance and knowledge which structure people's lives. ${ }^{31}$ Ewick and Silbey outline three schemas of legal consciousness: 'before the law', 'with the law' and 'against the law', summarising these as seeing the law respectively as authoritative and objective, as a game in which to participate and as something to be resisted. They note that these are not categories into which people can be put, but that people talk about their experiences using these conceptions in ways which are contingent and often contradictory. These varieties of legal consciousness, for all their fluidity, can help us to make sense of people's attitudes to law. Ewick and Silbey's theory of legal consciousness has been developed by Fritsvold ${ }^{32}$ and by Halliday and Morgan, ${ }^{33}$ who have identified a further variety of legal consciousness of a kind held by radical collective organisations which deny the authority of state law. Fritsvold describes this as 'under the law', while Halliday and Morgan describe it as 'dissenting collectivism'.

These insights from both the legal capability and the legal consciousness literature can help us to understand better what may have been happening with the reception of the Family Guide. The Guide aimed to inform contributors to the National Insurance scheme, emphasising its legal purpose, but with the standard caveat that it was not a complete statement of the law:

Important - This Guide is a general outline to help you to understand how the

Scheme will work. It must not be taken as an authoritative interpretation of the Law. ${ }^{34}$

The 'Law', capitalised in the original, is shown here to be all powerful, an example of what Ewick and Silbey have described as a 'before the law' legality, imagining 'law' as 'majestic' and above the everyday. ${ }^{35}$ In this view of legality, the aim of a booklet like this is to inform people of their rights, but also of their responsibilities: what they must do in order

29 Nigel Balmer, Alexy Buck, Ash Patel, Catrina Denvir and Pascoe Pleasence, Knowledge, Capability and the Experience of Rights Problems (Public Legal Education Network 2010).

30 Sally Engle Merry, Getting Justice and Getting Even: Legal Consciousness among Working Class Americans (University of Chicago Press 1990) 5.

31 Patricia Ewick and Susan Silbey, The Common Place of Law: Stories from Everyday Life (University of Chicago Press 1998).

32 Erik Fritsvold, 'Under the Law: Legal Consciousness and Radical Environmental Activism' (2009) 34 Law and Social Inquiry 799-824.

33 Simon Halliday and Bronwen Morgan, 'I Fought the Law and the Law Won? Legal Consciousness and the Critical Imagination' (2013) 66 Current Legal Problems 1-32.

34 Family Guide (n 1) 31.

35 Ewick and Silbey (n 31) 47. 
to be accepted into the imagined legal world of the welfare state which the Guide describes - a world in which everyone is included and protected but also one in which everyone also has a duty to contribute, a world of rights and rules.

On the one hand, those who misunderstood the booklet, or dismissed it as too difficult, may have lacked the resources to make sense of the information it contained: literacy, knowledge of government processes, awareness of recent public polices etc. The report concludes that many people who had not read or understood the Guide were driven by an expectation that it would be difficult or that it 'had nothing to do with them'. ${ }^{36}$ Here, some of the qualitative data included in the report can help us. For example, there are quotations from married women who had failed to understand the leaflet. In response to a question as to whether she might qualify for maternity benefit, a 'young farmer's wife' said 'Looks as if I don't get it.'; while another woman believed, wrongly, that she would have to pay National Insurance contributions: 'I thought I shouldn't have to pay but I've had a form sent me and it looks as if I must.' ${ }^{37}$ These responses display a rather passive approach to legal rights: an assumption that it had nothing to do with them, reflecting a 'before the law' approach. These respondents did not actively resist the role of law but saw it as something with which they must comply, even though they did not understand the rules.

On the other hand, some respondents may have taken a more resistant approach to the booklet. Although a good proportion of people interviewed by the researchers expressed support for the National Insurance scheme and estimated that they would benefit financially, some resistance to the scheme came from people who described themselves as 'middle class', who felt that they would lose out financially. ${ }^{38}$ An example of this is shown in the comment of a 'small shopkeeper' who thought that the system would be used to subsidise the health care of the poor, at his expense:

Why should I have to pay $5 / 1 \mathrm{~d}$ when I pay my doctor a fee anyway? $5 / 1 \mathrm{~d}$ for nothing. Its communism really. Working class - everything; middle class nothing. ${ }^{39}$

This respondent, like many, confused the National Insurance scheme with the NHS. His response illustrates some of the political objection to the post-war welfare state, coming from self-identifying middle-class people who did not recognise the world of inclusivity described in the Guide, seeing it instead as an intrusion on their economic liberties. This approach is resistant in the sense of not recognising the authority of the rules, seeing them as 'communism', a political system that the respondent rejected. We cannot tell from the survey whether the respondent intended to resist these rules in any active way, other than grumbling to the research interviewer.

At least one reader of the Guide reacted to the legal caveat as an excuse by the government to avoid the law. Writing to her local newspaper, a woman describing herself as a 'Farmer's wife' said: 'With my limited knowledge of law, I am convinced this notice exonerates the powers that be from any responsibility to meet their commitments.' She recommended that the Guides be 'sent back' and reissued with a statement that 'the government undertakes to meet its full responsibilities'. ${ }^{40}$ This woman exhibited a before the law consciousness: a belief that although the 'powers that be' were controlling the

36 Willcock (n 10) 21.

37 Ibid 32.

38 Ibid 7.

39 Ibid 14, quoting 'small shopkeeper'.

40 'Farmer's Wife', 'Letters Page' Courier and Advertiser (Dundee 2 June 1948) 2. 


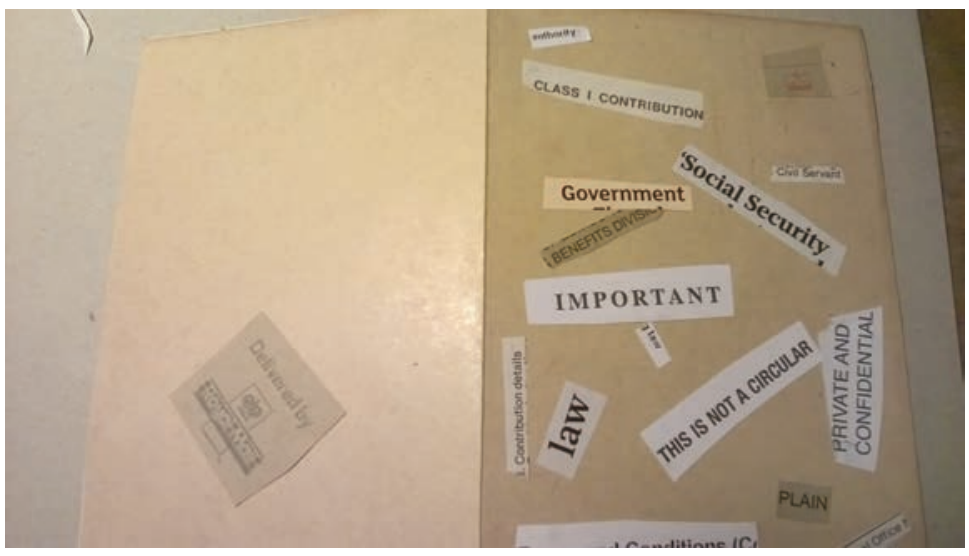

Figure 3: Family Guide model exterior

Photo by Jackie Gulland

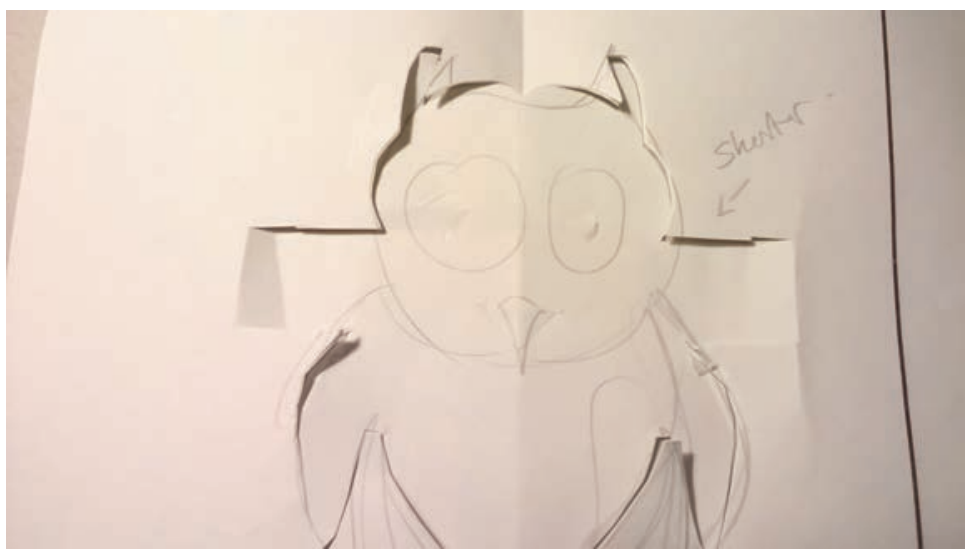

Figure 4: Prototype owl

Photo by Jackie Gulland

system, they were accountable to legal rules of conduct. This farmer's wife was suspicious that the government would not meet its new obligations. She was mistrustful of state power. This mistrust appears to be political but, unlike the 'small shopkeeper', she did not make this explicit. She did not seem to intend to use the law directly to challenge the activities of the government, but she could use her small powers of resistance by writing to her local newspaper.

These more resistant reactions to the Guide show that legal information is not neutral. It exists within a contested social and political context, with deep assumptions about gender, social class and mid-twentieth century ideas about the role of the welfare state. For some, the message of collectivism and inclusivity depicted in the Guide was welcome; for others, it exemplified 'communism'; but, for many, it described a bewildering, if perhaps benign, state bureaucracy. These different reactions to the Guide help to show us how a legal object such as this can be viewed from the different perspectives described by Prown, while, of course, our own reading of the object is wholly constructed by the cultural and political assumptions of our own time and place. ${ }^{41}$ 


\section{Making a model}

My participation in the SLSA conference Pop-Up Museum of Legal Objects required me to make a model of my object. I pondered on what form the model could take, thinking initially that the illustrations of owls were the most significant thing. My original plan was to make a model using a model owl with an umbrella to illustrate the inclusivity that the Guide promoted. However, having read the survey report, I began to think about the booklet differently. What seemed to be significant in 1948 was not the illustrations, which had struck me so forcefully, but the front cover, the beige paper, the official status of a Government leaflet. So my model took the form of a remade 'boring leaflet' (Figure 3):

I also wanted to recreate the owls and the effect that they had had on me, so I made a 'pop-up' owl, following instructions from a children's book on how make pop-up greetings cards (Figures 4 and 5).

This model represented my thinking about the booklet at the time: the conundrum of a quirky illustrated booklet containing boring information and

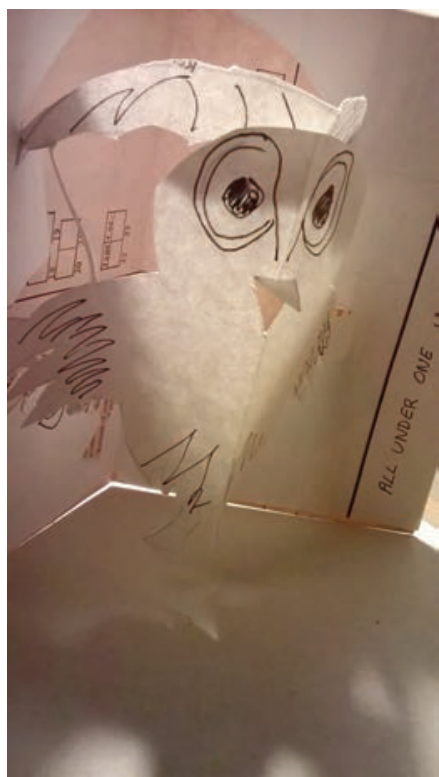

Figure 5: Family Guide model pop-ир owl

Photo by Jackie Gulland the apparent apathy that the original booklet evoked.

Making the model required an exercise in thinking differently, an exercise in 'engaging imagination' as recommended by James and Brookfield in their book on encouraging creative thinking in students. ${ }^{42}$ It required me to find a focus on what I wanted to say about the object. This moved my thinking from wondering about the illustrations to seeing the booklet as a piece of legal information. After I found the survey report, I began to think about the booklet through the eyes of its intended readers.

\section{Making a model: what I have learned}

The booklet is important as an example of a representation of the post-war National Insurance scheme in 1948 as new and exciting. The foreword concludes:

The success of this great Insurance Scheme depends upon the willing co-operation of every one of us . . . this scheme is therefore more than an Act of Parliament: it is an act of faith in the British people. ${ }^{43}$

This represents a mid-century enthusiasm for the welfare state and 'an act of faith'. It was part of a post-war project of national renewal and optimism in the role of collective provision for life's misfortunes. The Family Guide, with its cartoons of jolly owls, is a mechanism for promoting this vision. The new scheme may have been for everyone but only on condition of contributing, literally, through the National Insurance scheme and, in a wider sense, by signing up to the expectation of the male worker, the family wage and the dependent housewife. The booklet is a piece of propaganda, but it is also an attempt to inform people of their rights and duties under a new piece of legislation: an example of public legal information. The booklet continues to raise questions for me about public

42 Alison James and Stephen Brookfield, Engaging Imagination: Helping Students Become Creative and Reflective Thinkers (Jossey-Bass 2014) 83.

43 Family Guide (n 1) 3. 
understanding of welfare, mythologies of the past and the nature of rights. It provides a bridge between the early pre-war welfare system, with its connotations of conditionality, deservingness and links to the Poor Laws to a vision of a future welfare state where everyone was covered (literally, depicted with an umbrella) and where there was a legal contract between the state and the people to protect everyone from life's difficulties. My further investigations into the Guide and the discovery of the survey on its reception led me in a different direction, enabling me to think about the nature of public legal information and to make connections with recent debates on public legal education and legal consciousness. The physicality of this object means I continually come back to it, trying to make sense of what it represents. 